(๑) SW\&E, 2019

UDC 364-7:364-4

DOI: $10.25128 / 2520-6230.19 .2 .1$

\title{
ALTERNATIVE ACTIVITY AS A METHOD OF EMPOWERMENT AND MOTIVATION OF CLIENT TO THE CHANGE
}

\section{Olha Boyko,}

$\mathrm{PhD}$, Senior lecturer,

Pedagogy and Social Work

Department,

Ukrainian Catholic University,

Lviv, Ukraine.

Cell: (+38)0978046839;

e-mail: olha.boyko@ucu.edu.ua

ORCIDiD: 0000-0003-1449-4382

\section{Giancarlo Cursi,}

Dr. in Sociology and International

Politics,

Professor,

Pedagogical Methodology

Department,

Salesian Pontifical University,

Rome, Italy.

Cell: (+39)3473680628;

e-mail: gcursi@outlook.it

ORCIDiD: 0000-0003-4905-3413

\begin{abstract}
The article considers the method of alternative activity as a way of empowerment and of increasing the client's motivation to change a problem behavior in the technology of secondary or tertiary prevention. In particular, the authors highlight the main principles of the method; describe the algorithm of its implementation, its main characteristics and its impact on the growth of the client's motivation to change the problem behavior through engagement in the alternative activities. In addition, three examples of the method application in preventive projects with different target groups are presented. Thus, the article argues the relevance of the method of alternative activity in preventive social work with different groups of clients.
\end{abstract}

\section{Article history:}

Received: January 10, 2018

1st Revision: May 21, 2019

Accepted: June 30, 2019
Key words: method of alternative activities; prevention; strengths; empowerment; cognitive dissonance; motivation; change; problem behavior. 


\section{Introduction}

The method of alternative activity is one of the current methods in the technology of secondary or tertiary prevention. It is often used to prevent and overcome the deviant and, in particular, addictive behavior of adolescents and young people (Bezpalko, 2009; Zhuravel, 2013; Gant at al., 2000; Kelly, 2017; Rousseau et al., 2007) as a way of empowerment and of increasing their motivation to change the problem behavior. In spite of a wide application of the method in practical social work, in the Ukrainian scientific context, there is a lack of conceptualization of the method and of a description of the peculiarities of its application.

The theoretical foundations of the effectiveness of the method of alternative activity are based on the cognitive-behavioral theory: the process of reinforcement of behavior by the significant others (Bandura, 1977), the cognitive dissonance (Festinger, 1957), the process of change of behavior through increasing of the client's internal motivation (Prochaska\&DiClemente, 1986). Moreover, the method uses the concepts elaborated by the theories of interactionism: the social role, the stigma (Goffman, 2009) and the change of the social role (Blumer, 1969).

In the Ukrainian scientific context, the alternative activity is presented by Bezpalko (2009) and Zhuravel (2013) as an adjacent block of the prevention programs. The first author presents the alternative activity as one of the prevention's programs, namely a proposal of a positive action that would ensure to the individual strong feelings, an alternative to the deviant behavior that he/she already demonstrates. According to Zhuravel (2013) the alternative activity is an adjacent block of the prevention programs that, along with creating a supportive environment (another adjacent block), aims to reinforce the different components of the prevention's programs: cognitive, emotional, behavioral and value.

Despite the existence of a scientific argumentation of the relevance of the alternative activities in social-pedagogical work with adolescents and youth, it is not considered in practical guides on prevention. For example, in the latest methodical publication on the healthy lifestyle of youth (Andriuchenko et al., 2018), the program of the alternative activities is not considered. Methods of the interactive theatre, the lecture groups, the mobile consulting point, etc., that are proposed in the publication, use in their content the direct themes of the deviant behavior, what makes them relevant only as a primary prevention. The individuals or the groups that have already demonstrated a risky behavior can oppose participation in such activities. Therefore, in social work with such targets when it is necessary to motivate the change of the problem behavior, the alternative activity takes on particular importance.

We agree with the Bezpalko (2009) and Zhuravel (2013) on the core of the alternative activities in the context of the prevention`s technology. Besides, we would like to present the alternative activity as a separate method in a complex and integrated preventive intervention, that is a concrete way of achieving a goal of empowerment the client and of increasing his/her motivation to the change. The article aims to reveal the peculiarities of the method of the alternative activity in prevention technology as a way of empowerment and of increasing the client's motivation to change the problem behavior. According to the purpose, the objectives of the article are the following:

1) to identify the principles on which the method is based, and to argue its relevance in preventive social work with different groups of clients;

2) to describe the algorithm of implementation of the method of the alternative activity;

3) to identify the key characteristics of the method of the alternative activity;

4) to describe the mechanism for motivating the client to change the problem behavior by involving him/her in alternative activities. 


\section{Methodology}

In order to achieve the objectives of the article we have used such methods of analytical analysis as comparison, synthesis, grounding, and generalization. Initiating with the analysis of several practical cases of the projects that used the method of the alternative activity, we have recognized its main characteristics, the algorithm of its application, the principles on which it is based, and have confirmed its relevance for social and social pedagogical work.

\section{Key findings}

The method of the alternative activity consists in engagement of a person or a group that exhibits risky behavior or occurs in difficult life situations, in a specific positive activity that is not related directly to solving the problem but which may result in revealing strengths or resources of the person. The revealed potential should be supported by the positive recognition and encouragement of the significant others. So the person increases self-efficacy perception, changes the social environment to more safe and positive, reinforces social relationships and a network of support, receives a new social role. The discrepancy and cognitive dissonance between "old" and "new" social roles motivate the person to the change. On this basis, the next stage of professional intervention, which aims to resolve a problem situation or change a problem behavior, is built up.

The method of the alternative activity seems to be introductory for the direct work on the problematic behavior change in order to prevent the further risks or to reduce the harm. So it could be applied in the secondary prevention that aims to motivate the individual to change a problem behavior and to prevent the aggravation of the situation.

At this point let's analyze some real examples of the use of the alternative activity method in three different cases. They are: the project "Outdoor" of the Lviv City Public Organization "Community of Emaus-Oselya", working with homeless adult people (Lviv, Ukraine), the music-based intervention for homeless youth of Teen Living Programs Belfort House (Chicago) and the daytime multifunctional Center for Teenagers at the probation at Borgo Ragazzi Don Bosco (Rome, Italy).

In the Lviv City Public Organization "Community of Emaus-Oselya" practice there was the "street" magazine "Outdoor" - an interesting project that demonstrated the application of the method of the alternative activity (Sokha\&Sanotskaya, 2006). The innovation of the project consists in the fact that the homeless adults were involved in the different phases of the work on the magazine publication and distribution: as authors, they published their articles, poems along with famous writers and poets, they themselves sold the magazine on the streets of the city. According to the testimonials of the representatives of the target group involved in the project, the engagement in the project helped the homeless men and women gain a new social role, interact with the ordinary people communication with whom was deprived, encouraged them to change their life situation, and also contributed to the reduction of stigma towards the homelessness in the society.

The project Teen Living Programs Belfort House (Chicago) represents a similar example of the method implementation by involving the homeless youth in the different musical activities (musical instruments playing, singing, production, hip-hop). As the empirical study conducted by the results of the intervention (Kelly, 2017) demonstrates, the music studio participation provided the young people with a sense of social ties with the others through their mutual interest for the music and facilitated the building of relationships. The project participants emphasized the importance of the opportunity to 
develop their enthusiasm, despite of the difficult living conditions in which they occurred. As a result, they discovered and reinforced their strengths; developed new mechanisms of coping; reduced impulsivity; increased their resilience and changed their environment from the street to the more secure one.

Another example of the use of the method of the alternative activity is the activities of daytime multifunctional Center for Teenagers at the probation at Borgo Ragazzi Don Bosco (Rome, Italy). The Center's target group are teenagers who have demonstrated risky or deviant behavior or have been dropped out of school, including juvenile offenders involved in an alternative punishment program. The adolescent who enters the center receives an offer of different practically oriented professional trainings, that are attractive for young people (manicure and hairdressing, electronics and robotics, auto mechanics, restaurant business, etc.). Starting with daily systematic training of certain professional skills in peer groups and with the interactive methods use, the educational, psychological and social deficits of the individual are identified and a comprehensive project of social and pedagogical support is offered. This individual project usually includes the compensation of the school program and obtaining the secondary education certificate, the group or individual psychotherapy, the civic education program, etc. (Alfano, 2006). Thus, the offer of the practically oriented professional training in this program serves as a method for capturing the interest of a teenager, an alternative initial activity in order to implement a complex integrated intervention towards adolescent's problems solution.

\section{Discussion}

The method of the alternative activity corresponds to the main ethical principles of social pedagogical work: the principle of promotion of the self-realization of the client in all spheres of his/her life; the principle of a differentiated and personalized approach; the principle of relying on individual's potential and promoting the identification of its strengths and resources (Bezpalko, 2009). The application of the principles influences the motivation of the client to change a problem situation and to activate an own life position. In the social work this process in known as empowerment. According to this principle, the professional intervention should help individuals, families, groups and communities "to increase their personal, interpersonal, socioeconomic, and political strengths and develop an influence toward improving circumstances" (Zhuravsky et al., 2004, p. 62). The identification, activation and development of one's strengths and recourses are necessary in order to achieve his/her/their active position in solving the difficult circumstances of own life and become not only an ally of social worker but also a protagonist of the intervention (Boyko, 2016).

Prochaska D. and Di Clemente C. (1986) have developed the transtheoretical model of the behavioral change (1986) within the behavior change theories (Miller et al., 1986). According to the model during the process of the problem behavior change the client underpasses different stages: precontemplation stage (not ready to change), contemplation (thinking of changing, getting ready, maybe soon), determination (ready to change), action (making change), maintenance (staying on stage, possible relapse), termination (change fully integrated). The key aspect in this process is the one's readiness for change (Jones-Smith, 2016). On the first stage the motivation for the behavioral change is usually an external one - somebody from the close environment of the individual prompts him to begin a treatment of an addiction or to change the difficult life circumstances. The first contact with the social services or some specialist occurs mainly on this precontemplation stage. Therefore, the practitioner should 
accompany and stimulate the client to move to the next stages, up to the active involvement of the individual and action towards the change of own problem situation.

The key task in this process is to find the recourses of the client and to reinforce his/her social networks and especially the relations with the significant others who will support the process of change and encourage to not relapse. In this context, involving the client to some alternative activity is a method of identification of his/her strengths and of enhancing his/her social relations network.

After confirming the relevance of the alternative activity method, we will describe the algorithm of its implementation. The first step in applying the method is the initial analysis of the resources, strengths, and potential of the individual. This stage is an obligatory part of the diagnosis of any problem situation. It is important not only for the better understanding of the circumstances of the individual, family or group, but it also has strategic significance in order to find an alternative activity that will be accepted by the individual and will demonstrate and increase his/her resources. Mattaini and Meyer (2002) who consider the concept of the strengths in the ecosystems perspective emphasize that the strengths of the individual are manifested, first of all, in cooperation with others, in engagement and in active participation in a joint activity.

The second step is an elaboration of a program of an alternative activity and engagement of the individual to participate in. Such alternative activity could consist in involving into:

- preparation and holding of a leisure event (artistic, entertainment, sporting or cultural activities);

- labor activity (a certain type of professional or semi-professional activity that will help an individual to feel the importance of professional self-realization);

- helping someone else (volunteerism).

If we aim that the alternative activity results in emerging the potential of the individual and in motivating to change, it should be in congruence with the following requirements (Cursi, 2011):

1) To be based on the "zone of the growth" (Vygotskyy, 1992), that is correspond to the individual's potential capabilities, even being atypical or unfamiliar to him/her.

2) To be culturally appropriate to the individual's social environment. It is necessary that the social environment, in which the intervention and the alternative activity are carried out, corresponds to his/her natural environment. In this way the individual will be able to strengthen his/her social relationships, especially with those significant others who will support positive changes in his/her life.

3) To promote the reinforcement of social relationships and achieve the recognition and encouragement of the significant others. The mechanism of positive reinforcement is a universal cognitive mechanism of a consolidation of a behavior (Bandura, 1977), which is particularly important in work with the people who demonstrate low self-esteem.

Considering the managerial requirements of the method's application, the proposition of the alternative activities should be systematic and sustainable, realistic to the implementation, economically feasible and with the prospect of a further development (Cursi, 2011).

The main purpose of the method of the alternative activity is to offer the individual a new social role, based on his/her strengths and resources and ensuring a social recognition. This new alternative activity and the obtained social role should increase his/her self-esteem and develop the internal motivation to change the problem behavior or the situation. When the new social role and a personal growth of the individual are confirmed by the significant others, he/she personally feels the need to 
solve own problems, to work on own deficiencies and in this way to change the problem situation.

The development of an internal motivation is based on the psychological mechanism of cognitive dissonance (Festinger, 1957). This theory is one of the theories on changing the attitudes, which states that personality behaves in such a way that enables to maximize the internal sequence of his/her cognitive system. When some conflicting knowledge, ideas, beliefs or attitudes towards the object or the phenomenon encounter in the consciousness of the individual, it provokes an internal psychic conflict, that is, cognitive dissonance. Due to this, the individual feels a sense of frustration, dissatisfaction, incompleteness of life, that motivates him to reduce the feeling of dissonance (Stroebe, 2008).

The perception of the discrepancies between the obtained positive social role, the result of the alternative activity, and existing limitations, deficits, problems provoke the feeling of internal contradictions. The awareness of the individual's deficits and of the need of change could be facilitated by the practitioner who accompanies the client (the stage of the contemplation according to the model of behavioral change (Prochaska\&DiClemente, 1986)). Being attached to a new social role, the individual himself becomes motivated to change his/her difficult life circumstances, to work on deficiencies or fill own gaps.

Such process can be the result of self-development of the individual, but in the context of social and social pedagogical intervention it can only be possible with the well-projected support of a social worker, educator or psychologist. A strategic result of the method of the alternative activity is obtained when the client himself, due to the dissonance, asks to help him to change the fragility or the problematic behavior. Thus the change is no longer imposed or proposed just by the professional.

\section{Conclusion}

Thus, this study analyzes the method of the alternative activity, elaborates the algorithm of its implementation, reveals its main characteristics and highlights its relevance for primary and secondary prevention as well as for correction and rehabilitation programs. Since the method is based on the universal principles of social and social pedagogical work (co-participation, identification of strengths and empowerment) it seems to be important to extend the field of its application. The method of the alternative activity as an introductory intervention can be applied to a whole range of difficult life circumstances of individual, family, group or even community. Although the effectiveness of the method is empirically based (Alfano, 2006; Kelly, 2017; Rousseau et al., 2006), the further investigation may consist in some experimental research on the efficacy of the method of the alternative activity in preventive programs in favor of specific target groups.

\section{References}

Andriuchenko, T., Vakulenko, O., Volkov, V., Dzyuba, N., Kolyada, V., Komarova, N., Pesha, I., Tilikina, N. (2018). Healthy lifestyle education. Educational and methodical recommendations. Kyiv: "State Institute of Family and Youth Policy".

Boyko, O. (2016). Realization of the principle of empowerment as a guarantee of effectiveness of social services. In Economics, Science, Education: Integration and Synergy: Materials of the International Scientific and Practical Conference (Bratislava, January 18-21, 2016): 2 t. Kyiv: View of the Center for Educational Literature. 23. DOI: 10.13140 / RG.2.1.4200.8562

Bezpalko, O.V. (2009). Social pedagogy: diagrams, tables, comments: a manual. Kyiv: Center of Educational Literature. 
Street magazine "Outdoor". In Lviv city public organization "Community of mutual assistance" Emmaus - Oselya ". URI: http://emaus-oselya.org/ua/?page_id=230

Zhuravel, T.V. (2013). Social prevention as a direction of social and pedagogical activity. In Bezpalko OV (for ed.). Social pedagogy: teach. manual. Kyiv: Academic Edition, 2013. 85-101.

Zhuravsky, A., Baibakova, I., Haiduk, N. (2004). English-Ukrainian terminology dictionary: a guide to social work. Lviv.

Soha, M. \& Sanotka, O. (2008). All people have the potential: about the idea of self-help. Lviv: PAIS.

Alfano, A. (2006). Un progetto alternativo al carcere. I sussidi utilizzati nel Centro polifunzionale diurno di Roma. Roma: Centro Accoglienza "Don Bosco". CNOSFAP. Hall.

Bandura, A. (1977). Social Learning Theory. Englewood Clifs, N.J., Prentice

Blumer, H. (1969). Symbolic Interactionism. Berkeley: University of California.

Cursi, G (2011). Metodologia della prevenzione e della rieducazione: dispense per gli studenti. Roma, LAS.

Gant, L. M., Shimshock, K., Allen-Meares, P., Smith, L., Miller, P., Hollingsworth, L. A. \& Shanks, T. (2009). Effects of photovoice: Civic engagement among older youth in urban communities. Journal of Community Practice, 17(4), 358-376. doi:10.1080/10705420903300074

Goffman, E. (2009). Stigma: Notes on the Management of Spoiled Identity. New York: Simon and Schuster.

Festinger, L. (1957). A Theory of Cognitive Dissonance. Stanford, Calif.: Stanford University Press.

Jones-Smith, E. (2016). Theories of counseling and psychotherapy: An integrative approach (2nd ed.). Thousand Oaks, CA, US: Sage Publications, Inc.

Kelly B. L. (2017). Music-Based Services for Young People Experiencing Homelessness: Engaging Strengths and Creating Opportunities. Families in Society: The Journal of Contemporary Social Services. 98(1), 57-68. DOI: 10.1606/10443894.2017 .9

Mattaini, M. A., \& Meyer, C. H. (2002). The ecosystems perspective: Implications for practice. In M. A. Mattaini, C. T. Lowery, \& C. H. Meyer (Eds.), Foundations of social work practice: A graduate text (3rd ed.). Washington DC: NASW Press. 3-24.

Melandri E.B. (Ed.). (2011). La metà di me. Raccolta di storie ed esperienze di educazione non formale. Percorsi per l'inclusioen socio-culturale. Roma: Ministero del Lavoro e delle Politiche Sociali, CIES.

Prochaska D. \& DiClemente C. (1986). Towards a comprehensive model of change. In Miller, W. R. \& Heather, N. (Eds.), Treating Addictive Behaviours: Processes of Change. Plenum Publishing Corporation. 3-27.

Rousseau, C., Benoit, M., Gauthier, M. F., Lacroix, L., Alain, N., Rojas, M. V., \& Bourasaa, D. (2007). Classroom drama therapy program for immigrant and refugee adolescents: A pilot study. Clinical Child Psychology and Psychiatry, 12(3), 451-465. doi:10.1177/1359104507078477

Stroebe, W. (2008). Strategies of attitude and behaviour change. In Hewstone, M., Stroebe, W. \& Jonas, K. (Eds.). Introduction to social psychology. Oxford, UK: Blackwell. Lucie Press.

Vygotsky L. S. (1992). Educational Psychology. (or.pub. 1926). Florida: St. 


\title{
АЛЬТЕРНАТИВНА ДІЯЛЬНІСТЬ ЯК МЕТОД НАСНАЖЕННЯ ТА МОТИВАЦІЇ КЛІСНТА ДО ЗМІН
}

\author{
Ольга Бойко, PhD; стариа викладачка кафедри педагогіки та соціальної \\ роботи ВНЗ «Украӥнський Католицький Університет», Львів, Украӥна; \\ olha.boyko@ucu.edu.ua
}

Джіанкарло Курсі, доктор соиіологї та міжнародної політики, професор кафедри педагогічної методології Папського салезіянського університету, Рим, Iталія; gcursi@outlook.it

Анотація. У статті розглядається метод альтернативної діяльності у технології вторинної чи третинної профілактики як спосіб наснаження та формування мотивації клієнта до зміни проблемної поведінки. Його пропонують використовувати при попередженні та подоланні девіантної та, зокрема, адиктивної поведінки підлітків та молоді (Безпалько, 2009; Журавель, 2013; Gant at al., 2000; Kelly, 2017; Rousseau et al., 2007). Попри широке застосування методу у практичній соціальній роботі, в украӥнському науковому контексті бракує концептуалізації методу альтернативної діяльності та детальнішого опису особливостей його застосування.

Метою даної статті $\epsilon$ розкрити особливості методу альтернативної діяльності у технологї профілактики як способу наснаження клієнта та формування його мотиващії до змін. Цю мету було досягнуто за допомогою аналітичних методів порівняння, аналізу, синтезу та обгрунтування. Зокрема, на прикладі трьох різних випадків були проаналізовані реальні приклади застосування методу альтернативної діяльності: проект «вуличний» журнал «Просто неба» Львівської міської громадської організачії «Спільнота взаємодопомоги ЕмаусОселя», щуо працює із безпритульними людьми (Соха \& Саноцька, 2006); проекти Підліткових Життєвих Програм Белфорд Хаусу (Teen Living Programs Belfort House) y Чікаго (Kelly, 2017), проекти денного багатофункціонального центру для підлітків у прочесі пробаціï при Борго Рагащฺі Дон Боско (Borgo Ragazzi Don Bosco) y Pumi (Alfano, 2006).

У результаті дослідження було підтверджено, щзо теоретичні засади ефективності методу альтернативної діяльності трунтуються на проиесах, виявлених в рамках когнітивно-поведінкових теорій особистості: когнітивний дисонанс (Festinger, 1957), закріплення поведінки через визнання з боку значущих осіб (Bandura, 1977), зміна поведінки через внутрішню мотивацію клієнта (Prochaska \& DiClemente, 1986). Крім того, метод використовує поняття, опрацьовані теоріями інтеракціонізму: сочіальна роль та стигма (Goffman, 2009), зміна соціальної ролі (Blumer, 1969). У вітчизняній науковій літературі метод описаний Безпалько О.В. (2009) та Журавель Т. В. (2013) як супровідний блок програми профілактики.

Метод альтернативної діяльності полягає у тому, щоб залучити особу, яка демонструє ризиковану поведінку чи перебуває у складних житттєвих ситуачіях, до специфічної позитивної активності, щзо не пов'язана напряму із вирішенням проблемної ситуащії, але в результаті якої можуть виявитися ї̈ сильні сторони та ресурси. Виявлений потенціал особи підкріплюється заохоченням та визнанням з боку значущих для неї осіб. Таким чином, зростає самоочінка особи, відчуття само-ефективності, сочіальне середовище змінюється на більи безпечне та позитивне для ї̈ розвитку, особа отримує нову соціальну роль. Когнітивний дисонанс між «старою» та «новою» сочіальною 
роллю мотивує особу до зміни проблемної поведінки $і$ вона сама стає готова працювати над недоліками чи змінити ситуащію. На основі иієї внутрішньо мотивації вибудовується наступний етап професійного втручання, пов'язаний вже безпосередньо із вирішенням проблемної ситуації.

Для того, щьоб альтернативна діяльність призвела до виявлення потенціалу особи та мотивувала ї̈ до зміни, вона повинна відповідати таким характеристикам (Cursi, 2011): базуватися на «зоні росту» особи; залишатися культурно відповідною сочіальному середовищу особи; сприяти зміцненню сочіальних зв'язків особи та отримати визнання значущих для неї осіб.

У даному дослідженні було здійснено аналіз методу альтернативної діяльності у контексті програм вторинної та третиннї профілактики, було деталізовано алгоритм його здійснення, аргументовано актуальність методу у технологї профілактики та його пропедевтичність для корекційних та реабілітаційних програм.

Ключові слова: метод альтернативної діяльності; профілактика; сильні сторони; наснаження; когнітивний дисонанс; мотивація; зміна поведінки.

\section{Лimepamypa}

Андріученко, Т., Вакуленко, О., Волков, В., Дзюба, Н., Коляда, В., Комарова, Н., Пєша, I., Тілікіна, Н. (2018). Формування здорового способу життя. Навчально-методичні рекомендації. Київ: ДУ «Державний інститут сімейної та молодіжної політики».

Бойко, О. (2016). Реалізація принципу наснаження як запорука ефективності соціальних послуг. В Економіка, наука, освіта: інтеграція та синергія: матеріали міжнародної науково-практичної конференцї (Братислава, 18-21 січня 2016 року): у 2-х т. Київ: Вид-во «Центр навчальної літератури». 23. DOI: $10.13140 /$ RG.2.1.4200.8562

Безпалько, О.В. (2009). Соціальна педагогіка: схеми, таблиці, коментарі. Навч. посіб. Київ: Центр учбової літератури.

Вуличний журнал «Просто неба». In Львівська міська громадська організація «Спільнота взаємодопомоги «Емаус - Оселя». URI: http://emausoselya.org/ua/?page_id=230

Журавель, Т. В. (2013). Соціальна профілактика як напрям соціальнопедагогічної діяльності. В Безпалько О. В. (за заг. ред). Соціальна педагогіка: навч. посібник. Київ: Академвидав, 2013. 85-101.

Журавський, А., Байбакова, I., Гайдук, Н. (2004). Англо-український термінологічний словник-довідник із соціальної роботи. Львів.

Соха, М. \& Саноцька, О. (2008). Всі люди мають потенціал: Про ідею допомоги для самодопомоги. Львів: ПАІС.

Alfano, A. (2006). Un progetto alternativo al carcere. I sussidi utilizzati nel Centro polifunzionale diurno di Roma. Roma: Centro Accoglienza "Don Bosco". CNOSFAP. Hall.

Bandura, A. (1977). Social Learning Theory. Englewood Clifs, N.J., Prentice

Blumer, H. (1969). Symbolic Interactionism. Berkeley: University of California.

Cursi, G. (2011). Metodologia della prevenzione e della rieducazione: dispense per gli studenti. Roma, LAS.

Gant, L. M., Shimshock, K., Allen-Meares, P., Smith, L., Miller, P., Hollingsworth, L. A. \& Shanks, T. (2009). Effects of photovoice: Civic engagement among older youth in urban communities. Journal of Community Practice, 17(4), 358-376. doi:10.1080/10705420903300074 
Goffman, E. (2009). Stigma: Notes on the Management of Spoiled Identity. New York: Simon and Schuster.

Festinger, L. (1957). A Theory of Cognitive Dissonance. Stanford, Calif.: Stanford University Press.

Kelly B. L. (2017). Music-Based Services for Young People Experiencing Homelessness: Engaging Strengths and Creating Opportunities. Families in Society: The Journal of Contemporary Social Services. 98(1), 57-68. DOI: 10.1606/10443894.2017.9

Mattaini, M. A., \& Meyer, C. H. (2002). The ecosystems perspective: Implications for practice. In M. A. Mattaini, C. T. Lowery, \& C. H. Meyer (Eds.), Foundations of social work practice: A graduate text (3rd ed.). Washington DC: NASW Press. 3-24.

Melandri E.B. (Ed.). (2011). La metà di me. Raccolta di storie ed esperienze di educazione non formale. Percorsi per l'inclusioen socio-culturale. Roma: Ministero del Lavoro e delle Politiche Sociali, CIES.

Prochaska D. \& DiClemente C. (1986). Towards a comprehensive model of change. In Miller, W. R. \& Heather, N. (Eds.), Treating Addictive Behaviours: Processes of Change. Plenum Publishing Corporation. 3-27.

Rousseau, C., Benoit, M., Gauthier, M. F., Lacroix, L., Alain, N., Rojas, M. V., \& Bourasaa, D. (2007). Classroom drama therapy program for immigrant and refugee adolescents: A pilot study. Clinical Child Psychology and Psychiatry, 12(3), 451-465. doi:10.1177/1359104507078477

Stroebe, W. (2008). Strategies of attitude and behaviour change. In Hewstone, M., Stroebe, W. \& Jonas, K. (Eds.). Introduction to social psychology. Oxford, UK: Blackwell.

Vygotsky L. S. (1992). Educational Psychology. (or.pub. 1926). Florida: St. Lucie Press.Content-analysis of the professiogram of the social sphere specialists, competent in solving professional conflict 